\title{
Periodontal health in children with diabetes mellitus type 1 in Montenegro
}

\author{
Mirjana Đuričković ${ }^{1}$, Mirjana Ivanović ${ }^{2}$ Mira Samardžićs, Olivera Jovičić2 Zorica Popović $^{1}$ \\ ${ }^{1}$ University of Montenegro, Faculty of Medicine, Department of Dentistry, Podgorica, Montenegro; \\ ${ }^{2}$ University of Belgrade, Faculty of Dental Medicine, Clinic of Preventive and Pediatric Dentistry, Belgrade, Serbia; \\ ${ }^{3}$ Institute for diseased children, Podgorica, Montenegro
}

\begin{abstract}
SUMMARY
Introduction Separation of instruments in the root canal is one of the challenges in endodontic treatment. More specifically, nickel-titanium (NiTi) rotary instruments usually separate without previous deformation. The aim of this pilot study was to assess the effect of torsional stress on endodontic NiTi rotary instruments separation in simulated clinical conditions.

Materials and methods Research was conducted on a sample of 20 human teeth in laboratory conditions. Experimental procedure consisted of determining canal curvatures for each root on digital radiographs and root canal treatment using endodontic NiTi rotary instruments. Out of 20 teeth (60 canals), two groups were formed with similar root canal curvatures (10 pairs of teeth) and instrumented using NiTi rotary instrument with or without torque control.

Results Wilcoxon matched pair test showed no statistically significant difference in average number of instruments use with or without torque control ( $p>0.05)$.

Conclusion Even though there is no statistical significance in instrument separation when instruments were used with or without torque, there is tendency to experience sudden fracture of instruments after work without torsional control even after only few uses in clinical work.
\end{abstract}

Keywords: nickel-titanium rotary instruments; torque; separation

\section{INTRODUCTION}

Diabetes mellitus (DM) is systemic metabolic disorder characterized by hyperglycemia (a persistent increase in blood glucose level) resulting from insulin secretion disorder, disturbance of its function or both [1,2]. It is one of the most common endocrine disorders, with prevalence in the constant rise especially in developed countries. This is due to the modern lifestyle and increase in the number of external etiological factors, among which obesity is particularly noticeable. DM is most common in older age as a result of general degenerative and sclerotic changes in the body (which also involve pancreas) while in children it may be due to genetic disorders or pancreas damage in certain infectious diseases $[1,2]$.

The incidence of DM in childhood is constantly increasing. The number of children with DM doubles every other decade. Every ten seconds in the world one person dies of diabetes, and two new ones get sick. Children in $98 \%$ of cases experience unstable, ketosis-related, insulin-dependent diabetes mellitus (type 1), which is most commonly diagnosed in puberty $[2,3]$. Like all systemic diseases, DM gives many complications. The significant impact of this disease is on oral health.

Large number of studies has shown that prevalence, progression and severity of periodontal diseases have been significantly increased in patients with DM. The on- set and progression of periodontitis in patients with DM is probably caused by diabetic microangiopathy, impaired immune response and reduced resistance to infection. In patients with DM, periodontal disease occurs at younger age compared to healthy population. In children with DM, periodontal damage is usually manifested in adolescence, and very often earlier $[4,5]$.

The aim of this study was to determine whether periodontal health of children with type 1 diabetes mellitus was different from healthy children.

\section{METHODS}

Ethical Committee of the Clinical Center in Podgorica, Montenegro approved this research. One dentist performed all examinations. Kappa values evaluated after the study for inter-rater agreement amounted to 0.94 .

The study included 87 children of both genders, aged 10-15 years, suffering from Type 1 diabetes mellitus (DMT1) from all over Montenegro. These children were treated at the Institute of Child Diseases in the Clinical Center of Montenegro. Only those children whose parents had given their consent were included in the examinations. Data about history of disease, including the type of $\mathrm{DM}$ and values of glycosylated hemoglobin (HbAlc) not older than six months, were obtained from the medical 
records of patients. These children were included in one group (DMT1).

The control group included 90 healthy children of both genders; age 10-15 years, selected by random sampling method, and attending elementary school in the area of Podgorica municipality. Their parents also signed informed consent. All children who participated in the study were examined with standard dental diagnostic tools on dry teeth, with artificial lighting in dental chair.

The condition of oral hygiene was determined by Green-Vermilion plaque index, which determines the absence or the presence, quantity and distribution of dental plaque and other soft deposits on representative permanent teeth [6]. Loe-Silness gingival index was used for the clinical assessment of gingival tissue health on vestibular, oral, mesial and distal surfaces of each tooth [7]. Community Periodontal Index [8] was used to assess the condition of periodontal tissue according to the recommendations of the British Association for Periodontology and the British Association for Pediatric Dentistry (Guidelines for Periodontal Screening and Management of Children and Adolescents Under 18 Years of Age) [9]. For this purpose, special periodontal probe marked at 1,2, 3, 5,7,9 and 10 $\mathrm{mm}$, with $0.5 \mathrm{~mm}$ diameter ball at the end was used. This graduated probe was adapted for precise measurement of the clinical attachment level or periodontal pockets.

During examination, with slight pressure, the probe was introduced into the space between the teeth and gingiva, with the anatomical configuration of the teeth being monitored. The pressure at this measurement was $15-20 \mathrm{~g}$ and much lighter than the pressure used in usual probing of periodontal pockets [8]. For this purpose, the following representative teeth were examined: upper and lower first permanent molars, upper right first permanent incisor and lower left first incisor. For each tooth the following four measurements were conducted: mesiobucal, bucal, distal and oral. Depending on the clinical finding, each quadrant received appropriate score. The scoring was done as follows:

Score 0 - healthy periodontal tissue;

Score 1 - gingival bleeding after probing;

Score 2 - the presence of solid deposits on teeth (supra and subgingival calculus) or the existence of prominent edges of the fillings;

Score 3 - shallow periodontal pockets $4-5 \mathrm{~mm}$;

Score 4 - deep periodontal pockets (6 $\mathrm{mm}$ or more).

Out of these four, the finding indicating the worst condition of periodontal tissue was recorded. For each quadrant, only one digit 0 - 4 was determined, which represented the worst condition in that quadrant. If some of the representative teeth were missing, that quadrant was not taken into account. Thus, for each respondent, the individual maximum value of this index was determined and it indicated the need for and type of necessary treatment.

It should be emphasized that it is not recommended to measure the pockets depth in children 7 to 11 years old. In children under 12 years of age, periodontal health was determined based on the clinical state of gingiva and presence of solid deposits [9].

In our study, children under the age of 12 also did not have CAL measured, while for children older than 11 years the same teeth were used as for CPI index [9]. The measurement was performed by graduated dental probe with a ball on the top, in the middle of the vestibular surface and at the connection of mesial and vestibular surface. The probe was placed in the sulcus parallel to the longitudinal tooth axis [9]. The measurement results were given for each representative tooth.

For descriptions of parameters and depending on their nature, the descriptive statistics were used: mean value, standard deviation (SD) and percentage. To test statistical significance of average values between two independent samples, Student's t-test and Mann-Whitney test were used. $P$ values of less than 0.05 were considered statistically significant. Statistical data processing was done in SPSS v.11.5 for Windows.

\section{RESULTS}

A total of 177 children aged 10-15 years participated in the study. The average age of children suffering from DMT1 was $12.7 \pm 1.6$, while the average age of children from the control group was $12.8 \pm 1.6$.

In the sample of children with DM, the mean PI was $1.31 \pm 0.55$, while the average value of this indicator in the control group of children was $1.03 \pm 0.51$. Children with diabetes had significantly higher average plaque index values compared to healthy children (Table 1).

Table 1. Values of Plaque Index (PI), Community Periodontal Index $(\mathrm{CPI})$ and Clinical Attachment level $(\mathrm{CAL})$ in both groups

Tabela 1. Vrednosti plak indeksa, zajedničkog parodontalnog indeksa i nivoa pripojnog epitela u obe grupe

\begin{tabular}{|l|c|c|c|}
\hline & DMT1 & \multicolumn{2}{|c|}{$\begin{array}{c}\text { Control group } \\
\text { Kontrolna grupa }\end{array}$} \\
\hline $\begin{array}{l}\text { Parameter } \\
\text { Parametar }\end{array}$ & $\begin{array}{c}\text { Mean } \pm \mathrm{sd} \\
\text { Srednja vrednost } \pm \mathrm{sd}\end{array}$ & $\begin{array}{c}\text { Mean } \pm \mathrm{sd} \\
\text { Srednja vrednost } \pm \mathrm{sd}\end{array}$ & $\mathrm{p}$ \\
\hline $\mathrm{PI}$ & $1.31 \pm 0.55^{*}$ & $1.03 \pm 0.51^{*}$ & 0.001 \\
\hline $\mathrm{CPI}$ & $1.36 \pm 1.12^{*}$ & $0.59 \pm 0.84^{*}$ & 0.000 \\
\hline $\begin{array}{l}\mathrm{CAL} \\
\text { NPE }\end{array}$ & $1.33 \pm 0.60^{*}$ & $0.66 \pm 0.53^{*}$ & 0.000 \\
\hline
\end{tabular}

* statistical significance of Student's t-test

* statistička značajnost Studentovog t-testa

Of the total number of children in the group DMT1, healthy gingiva was found in $6.8 \%$, mild inflammation in $17.2 \%$, moderate inflammation in $58.6 \%$, and severe inflammation in $17.2 \%$ of children. In the control group, healthy gingiva had $26.7 \%$ of children, mild inflammation $43.3 \%$, moderate inflammation $22.2 \%$ and severe $7.8 \%$. Respondents from the DMT1 group had the highest percentage of moderate and severe gingival inflammation while subjects in the control group had more healthy gingiva and mild inflammation (Table 2). There was significant difference in gingival health between control and DMT1 group ( $\mathrm{p}<0.05$; Mann-Whitney test).

Significantly higher percentage of children with healthy periodontal tissue was registered in the control group $55.6 \%$ ( $\mathrm{p}<0.05$; Mann-Whitney test). On the other hand, in children with DM, the highest percentage of children had gingival bleeding (36.7\%) which was statistically 
Table 2. Gingival health of children in both groups Tabela 2. Zdravlje gingive kod dece $u$ obe grupe

\begin{tabular}{|l|c|c|c|c|}
\hline \multirow{2}{*}{ Gingival index (GI) } & \multicolumn{4}{c|}{$\begin{array}{c}\text { Group } \\
\text { Grupa }\end{array}$} \\
\cline { 2 - 5 } \begin{tabular}{l} 
Gingivalni indeks (GI) \\
\cline { 2 - 5 }
\end{tabular} & \multicolumn{2}{|c|}{ DMT1 } & \multicolumn{2}{c|}{$\begin{array}{c}\text { Control group } \\
\text { Kontrolna grupa }\end{array}$} \\
\cline { 2 - 5 } & $\mathrm{n}$ & $\%$ & $\mathrm{n}$ & $\%$ \\
\hline $\begin{array}{l}\text { Normal gingiva } \\
\text { Zdrava gingiva }\end{array}$ & 6 & $6.8^{*}$ & 24 & $26.7^{*}$ \\
\hline $\begin{array}{l}\text { Mild inflammation } \\
\text { Blaga upala }\end{array}$ & 51 & $58.6^{*}$ & 20 & $22.2^{*}$ \\
\hline $\begin{array}{l}\text { Moderate inflammation } \\
\text { Srednja upala }\end{array}$ & 15 & $17.2^{*}$ & 7 & $7.8^{*}$ \\
\hline $\begin{array}{l}\text { Severe inflammation } \\
\text { Jaka upala }\end{array}$ & 87 & 100 & 90 & 100 \\
\hline $\begin{array}{l}\text { Total } \\
\text { Ukupno }\end{array}$ & & & 39 & $43.3^{*}$ \\
\hline
\end{tabular}

${ }^{*} \mathrm{p}<0.05 ;$ Mann-Whitney test

${ }^{*} \mathrm{p}<0.05 ;$ Man-Vitnijev test

Table 3. CPI index in children of both groups

Tabela 3. CPI u obe grupe ispitivane dece

\begin{tabular}{|l|c|c|c|c|}
\hline \multirow{2}{*}{ CPI } & \multicolumn{4}{c|}{$\begin{array}{c}\text { Group } \\
\text { Grupa }\end{array}$} \\
\hline & \multicolumn{2}{|c|}{ DMT1 } & \multicolumn{2}{c|}{$\begin{array}{c}\text { Control group } \\
\text { Kontrolna grupa }\end{array}$} \\
\hline & $\mathrm{n}$ & $\%$ & $\mathrm{n}$ & $\%$ \\
\hline 0 & 21 & $24.1^{*}$ & 50 & $55.6^{*}$ \\
\hline 1 & 32 & 36.7 & 28 & 31.1 \\
\hline 2 & 15 & $17.2^{*}$ & 7 & $7.8^{*}$ \\
\hline 3 & 19 & $21.8^{*}$ & 5 & $5.6^{*}$ \\
\hline 4 & 0 & 0 & 0 & 0 \\
\hline $\begin{array}{l}\text { Total } \\
\text { Ukupno }\end{array}$ & 89 & 100 & 90 & 100 \\
\hline
\end{tabular}

${ }^{*} \mathrm{p}<0.05 ;$ Mann-Whitney test

${ }^{*} \mathrm{p}<0.05 ;$ Man-Vitnijev test

significant ( $\mathrm{p}<0.05$; Mann-Whitney test). Healthy periodontal tissue in DMT1 group was recorded in $24.1 \%$ of children, while the presence of solid deposits was registered in $17.2 \%$. The presence of periodontal pockets of $4-5 \mathrm{~mm}$ was found in $21.8 \%$. Respondents from the control group had bleeding after probing in $31.1 \%$, solid deposits in $7.8 \%$, and $4-5 \mathrm{~mm}$ pockets in $5.6 \%$ of examined children (Table 3). Children with DM compared to children in the control group had significantly worse periodontal disease ( $\mathrm{p}<0.05$; Mann-Whitney test). The score 4 for CPI index value was not registered in any group.

The average value of CPI index in the DMT1 group was $1.36 \pm 1.12$ and it was significantly higher $(t=5.58$; $\mathrm{p}=0.000)$ compared to members of the healthy group $(0.59 \pm 0.84)$ (Table 1$)$.

The mean value of CAL in children with DMT1 was 1.33 \pm 0.60 while in healthy children it was $0.66 \pm 0.53$ (Table 1 ). Healthy children had significantly lower clinical attachment level than children with $\mathrm{DM}(\mathrm{t}=5.58 ; \mathrm{p}=0.000)$.

\section{DISCUSSION}

The results of studies found in literature indicated that children with DMT1 had poorer oral hygiene, higher incidence and severity of gingivitis compared to healthy children. Likewise, we found that healthy children had more often healthy periodontal tissues. Gingival bleeding after probing was more common in the group of DMT1. Most studies concluded that the incidence of gingivitis in patients with DMT1 was significantly higher than in healthy population and increased with age [10]. In her research, Dakovic found that children with DMT1 in Serbia had more dental plaque, gingivitis and periodontal destruction, which is in agreement with the results of our study [11]. In large Brazilian study, it was found that children with DM had higher percentage of gingivitis and periodontitis compared to healthy children [12]. Children with DMT1 in Lithuania and Turkey had more dental plaque and worse gingival health than healthy children, which is in correlation with the results of our study $[13,14]$. Increased glucose levels in gingival fluid and blood and decreased salivary secretion in patients with DM changes micro flora causing qualitative changes in bacteria that are responsible for the occurrence of periodontal problems $[13,15]$. Karjalainen et al. noted that unbalanced glucose metabolism in diabetic patients is in direct correlation with the degree of gingival inflammation [16]. The pronounced gingival bleeding due to hyperglycemia can be explained by immunological changes occurring due to reduced resistance to organic deposits in dental plaque. Periodontal disease is reported as the sixth complication of diabetes mellitus [4]. The prevalence, severity and progression of periodontal disease are higher in these patients compared to healthy subjects [10, 17-21]. Dakovic et al. obtained similar results in children with DMT1 in Serbia [11]. Also, the study of Lalla et al. confirmed higher periodontal destruction in children with DMT1 than in healthy children [17]. Nevertheless, the results of certain studies have not found significant difference in periodontal disease between children with well-controlled DM and healthy children [19, 22]. Oral hygiene habits play an important role in preservation and health of periodontal tissues and prevalence of this disease varies depending on the health habits of each person.

Periodontal disorders begin very early in these children, with tendency to deteriorate periodontal tissues in adolescence. DMT1 adolescents develop earlier and advanced inflammatory reaction of gingiva compared to similar bacterial challenge in healthy children. In addition, it has been shown that severe damage of periodontal tissue occurs more frequently in patients with $\mathrm{DM}$ who ere poorly metabolically regulated $[10,11,17,18,19]$. Therefore, programs for prevention of disease and promotion of periodontal health should be available as soon as possible to this population group $[10,11,23]$.

DM is chronic metabolic disease that affects the entire body, as well as oral health. Health habits are very important in the prevention of oral diseases. Dentists should be focused on promoting good health and oral habits, performing periodic dental examinations and ensuring good oral hygiene in this population group. Dentists must minimize the risk factors for the occurrence of periodontal tissue diseases caries and other soft tissue disorders, as well as to carry out continuous health work and motivation of these patients with regards to oral hygiene [13]. 


\section{CONCLUSION}

The results of the current study indicate that children with type 1 diabetes mellitus in Montenegro have more dental plaque, more gingivitis and periodontal disorders than healthy children. It is necessary to propose a plan of preventive activities aimed to educate and implement prophylactic measures related to reduction of dental plaque and dental calculus.

\section{REFERENCES}

1. Patterson C, Gyrs E, Rosenbauer J, Cinek O, Neu A, Schober E, et al. Trends in childhood type 1 diabetes incidence in Europe during 1989-2008: evidence of non-uniformity over time in rates incidence. Diabetologia. 2012; 55(8):2142-7.

[DOI: 10.1007/s00125-012-2571-8] [PMID: 22638547]

2. Samardžić $M$, Martinović $M$, Nedović-Vuković $M$, PopovićSamardžić M. Novi podaci o incidenciji dijabetesa tipa 1 u Crnoj Gori: bolest počinje u mlađoj životnoj dobi. Acta Clin Croat. 2016; 55:63-8. [DOI: 10.20471/acc.2016.55.01.10]

3. Samardžić M, Popović N, Popović-Samardžić M, Nedović-Vuković M. Rising incidence of childhood type 1 diabetes in Montenegro. Srp Arh Celok Lek. 2016; 144(7-8):408-12.

[DOI: 10.2298/SARH1608408S] [PMID: 16641173]

4. Loe H. Periodontal disease: the sixth complication of diabetes mellitus. Diabetes Care. 1993; 16:329-34.

5. Novotna M, Podzimek S, Broukal Z, Lencova E, Duskova J. Periodontal diseases and dental caries in children with type 1 diabetes mellitus. Mediators Inflamm. 2015; 2015:379626. [DOI: 10.1155/2015/379626] [PMID: 26347009]

6. Greene JC, Vermillion JR. The Simplified Oral Hygiene Index. J Am Dent Assoc. 1964; 68:7-13. [PMID: 14076341]

7. Loe H. The Gingival Index, the Plaque Index and the Retention Index Systems. J Periodontol. 1967; 38:610-6. [DOI: 10.1902/jop.1967.38.6.610] [PMID: 5237684]

8. World Health Organization. Oral Health Surveys. Basic Methods, 4th edn. Geneva: World Health Organization, 1997.

9. Clerehugh V. Periodontal disease in children and adolescents: Brithis Dental J. 2008; 204:469-71.

10. Lalla E, Cheng B, Lal S, Tucker S, Greenberg E, Goland R, et al. Periodontal changes in children and adolescents with diabetes. Diabetes Care. 2006; 29:295-9.

[DOI: 10.2337/diacare.29.02.06.dc05-1355] [PMID: 16443876]
11. Daković D, Pavlović MD. Periodontal disease in children and adolescents with type 1 diabetes in Serbia. J Periodontl. 2008; 79(6):987-92. [DOI: 10.1902/jop.2008.070549] [PMID: 18533774]

12. Xavier ACV, Silva IN, Costa DO, Correa DS. Periodontal status in children and adolescents with type 1 diabetes mellitus. Arq Bras Endocrinol Metab. 2009; 53(3):348-54.

13. Siudikiene J, Machiulskiene V, Dobrovolskiene R, Nedzelskiene I. Oral hygiene in children with type 1 diabetes mellitus. Stomatologija. 2005; 7(1):24-7. [PMID: 16254474]

14. Orbak R, Simsek S, Orbak Z, Kavrut F, Colak M. The influence of type 1 diabetes mellitus on dentition and oral health in children and adolescents. Yonsei Med J. 2008; 49(39):357-65. [DOI: 10.3349/ymj.2008.49.3.357] [PMID: 18581583]

15. Klokkevold PR, Maeley BL, Carranza FA. Influence of systemicdisease and disorders on the periodontium. In Newman MG, Takei $\mathrm{HH}$, Carranza FA, editors. Carranza's clinical periodontology. $9^{\text {nd }}$ ed. Philadelphia: Sauders; 2002. p. 204-28.

16. Karjalainen KM, Knuttila ML. The onset of diabetes poor metabolic control increases gingival bleeding in children and adolescents with insulin-dependent diabetes mellitus. J Clin Periodontol. 1996; 23(12):1060-7. [DOI: 10.1111/j.1600-051X.1996.tb01804.x] [PMID: 8997648]

17. Lalla E, Cheng B, Lal S, Kaplan S, Softness B, Greenberg E, et al. Diabetes mellitus promotes periodontal destruction in children. Clin Periodontol. 2007; 34(4):294-8. [DOI: 10.1111/j.1600-051X.2007.01054.X] [PMID: 17378885]

18. Lal S, Cheng B, Kaplan S, Softness B, Greenberg E, Goland RS, et al. Gingival bleeding in 6 to 13 - year - old children with diabetes mellitus. Pediatr Dent. 2007; 29(5):426-30. [PMID: 18027779]

19. Pinson M, Hoffman WH, Garnick J), Litaker MS. Periodontal disease and type I diabetes mellitus in children and adolescents. I Clin Periodontol. 1995; 22:118-23. [PMID: 7775667]

20. Arheiam A, Omar S. Dental caries experience and periodontal treatment needs of 10- to 15-year old children with type 1 diabetes mellitus. Int Dent J. 2014; 64(3):150-4. [DOI: 10.1111/idj.12091] [PMID: 24506709]

21. del Valle LML, Ocasio-López C. Comparing the oral health status of diabetic and non-diabetic children from Puerto Rico: a casecontrol pilot study. Puerto Rico Health Sci J. 2011; 30(3):123-7. [PMID: 21932712]

22. lughetti L, Marino R, Bertolani MF, Bernasconi S. Oral health in children and adolescents with ID DM - a review. J Pediatr Endocrinol Metab. 1999; 12:603-10. [DOI: 10.1515/JPEM.1999.12.5.603] [PMID: 10854189]

23. Rafatjou R, Razavi Z, Tayebi S, Khalili M, Farhadian M. Dental health status and hygiene in children and adolescents with type 1 diabetes mellitus. J Res Health Sci. 2016; 16(3):122-6. [PMID: 27840339] 


\title{
Parodontalno zdravlje kod dece obolele od dijabetesa melitusa tipa 1 u Crnoj Gori
}

\author{
Mirjana Đuričković 1 , Mirjana Ivanovićz, Mira Samardžić ${ }^{3}$, Olivera Jovičić ${ }^{2}$, Zorica Popović \\ 'Univerzitet Crne Gore, Medicinski fakultet, studijski program Stomatologija, Podgorica, Crna Gora; \\ ${ }^{2}$ Univerzitet u Beogradu, Stomatološki fakultet, Klinika za dečju i preventivnu stomatologiju, Beograd, Srbija ; \\ Institut za bolesti djece, Podgorica, Crna Gora
}

\begin{abstract}
KRATAK SADRŽAJ
Uvod Dijabetes melitus (DM) u dečjem uzrastu može negativno da utiče na oralno zdravlje. Cilj ovog istraživanja je bio utvrđivanje stanja zdravlja parodoncijuma kod dece obolele od dijabetesa melitusa tipa I u odnosu na zdravu decu.

Metode U studiju je bilo uključeno 177 dece uzrasta 10-15 godina. Ispitanici su podeljeni u dve grupe. Osamdeset sedmoro dece obolelo od dijabetesa melitusa tipa 1 (DMT1) bilo je uključeno u prvu grupu. Drugu, kontrolnu grupu, njih 90, predstavljala su zdrava deca. Samo ona deca čiji su roditelji svojim potpisom dali saglasnost bila su uključena u studiju. Za utvrđivanje oralne higijene primenjivan je plak indeks (PI) po Green-Vermillionu. Stanje zdravlja gingive procenjeno je pomoću gingivalnog indeksa (Gl), opisanog po Löe-Silnessu. Procena stanja parodoncijuma registrovana je primenom CPI indeksa (Community Periodontal Index) i merenjem nivoa pripojnog epitela (NPE).

Rezultati Prosečna vrednost PI za obolelu decu iznosila je $1,31 \pm 0,55$, a za zdravu populaciju $1,03 \pm 0,51$, što je bilo statistički visoko značajno ( $p=0,001)$. Ispitanici iz grupe dijabetičara imaju procentualno najviše zastupljenu umerenu i tešku inflamaciju gingive, dok ispitanici iz kontrolne grupe imaju najviše zastupljenu zdravu gingivu i blagu inflamaciju $(p<0,05)$. Prosečna vrednost CPI indeksa u grupi dece sa DM bila je $1,36 \pm 1,12$, a u kontrolnoj grupi dece $0,59 \pm 0,84$, što je bilo statistički značajno $(p=0,000)$. Prosečna vrednost nivoa pripojnog epitela za decu obolelu od dijabetesa melitusa iznosila je 1,33 $\pm 0,60$ i bila je znatno viša $(p=0,000) u$ odnosu na pripadnike kontrolne grupe 0,66 $\pm 0,53$.

Zaključak Deca obolela od dijabetesa melitusa tipa 1 imaju više dentalnog plaka, lošije zdravlje gingive i više promena na parodoncijumu u odnosu na decu iz kontrolne grupe .

Ključne reči: deca; dijabetes melitus tip 1; oralna higijena; gingiva; parodoncijum
\end{abstract}

\section{UVOD}

Šećerna bolest je neizlečivi sistemski poremećaj metabolizma, a karakteriše se hiperglikemijom (trajno povećanim nivoom glukoze u krvi), nastalom kao posledica poremećaja sekrecije insulina ili poremećajem njegove funkcije, ili delovanjem oba činioca istovremeno $[1,2]$. Dijabetes se danas ubraja među najčešća endokrinološka oboljenja, sa prevalencom u stalnom porastu posebno u razvijenim zemljama sveta. To je posledica modernog stila života i povećanja broja spoljašnjih etioloških činjenica, među kojima se posebno izdvaja gojaznost. Šećerna bolest se najčešće javlja u starijem životnom dobu kao posledica opštih degenerativnih i sklerotičnih promena u organizmu (koje zahvataju i pankreas), a kod mlađih osoba i dece može nastati usled genetičkih poremećaja ili oštećenja pankreasa kod određenih infektivnih oboljenja [1,2].

Učestalost šećerne bolesti u dečjem uzrastu je u stalnom porastu. Broj novoobolelih udvostručuje se svake druge decenije. Svakih deset sekundi u svetu jedna osoba umre od dijabetesa, a dve nove se razbole. Deca u $98 \%$ slučajeva obolevaju od nestabilnog, ketozi sklonog, insulin-zavisnog dijabetesa melitusa (tip 1), koji se najčešće javlja u pubertetu [2,3]. Kao i sva sistemska oboljenja, dijabetes daje mnoge komplikacije. Značajan uticaj ove bolesti je na oralno zdravlje.

Brojne studije su pokazale da su prevalencija, progresija i težina oboljenja parodoncijuma značajno povećane kod pacijenata sa dijabetesom. Dijabetes je važan faktor rizika za nastanak oboljenja parodoncijuma. Početak i progresija parodontitisa kod pacijenata sa DM verovatno su izazvani dijabetičnom mikroangiopatijom, oštećenim imunim odgovorom kao i manjom otpornošću na infekcije. Kod obolelih od DM, oboljenja parodoncijuma se javljaju u mlađem uzrastu u odnosu na zdravu populaciju. Kod dece sa DM, oštećenja parodoncijuma se obično manifestuju u adolescenciji, a vrlo često i ranije $[4,5]$.

Cilj ovog istraživanja je bio da se utvrdi da li je parodontalno zdravlje dece obolele od dijabetesa melitusa tipa 1 drugačije od onog kod zdrave dece.

\section{METODE}

Za ova istraživanja je dobijena saglasnost Etičkog komiteta Kliničkog centra Crne Gore u Podgorici. Sve kliničke preglede obavio je jedan stomatolog. Kappa vrednosti procenjene nakon ponovnog pregleda za intrakonzistenciju istraživača iznosila je 0,94 .

Ispitivanjem je obuhvaćeno 87 dece oba pola, uzrasta 10-15 godina, obolele od dijabetesa melitusa tipa 1 iz svih krajeva Crne Gore. Ova deca se leče na Institutu za bolesti dece Kliničkog centra Crne Gore. U ispitivanja su bila uključena samo ona deca čiji su roditelji svojim potpisom dali saglasnost. Podaci o istoriji bolesti, uključujući DMTI vrednosti glikoziliranog hemoglobina (HbA1c), ne stariji od šest meseci, dobijeni su iz medicinske dokumentacije bolesnika. Ova deca su sačinjavala jednu grupu (grupa dijabetičara D) ispitanika.

Drugu, kontrolnu grupu, predstavljala su zdrava deca oba pola, uzrasta 10-15 godina, ukupno njih 90, izabrana metodom slučajnog uzorka, a koja pohađaju osnovnu školu na području podgoričke opštine. Realizacija studije je otpočela nakon dobijanja pismene saglasnosti roditelja. Sva deca koja su učestvovala u istraživanju pregledana su standardnim stomatološkim dijagnostičkim sredstvima na suvim zubima, pri veštačkom osvetljenju na stomatološkoj stolici.

Stanje oralne higijene utvrđeno je pomoću plak indeksa po Greene-Vermilionu, kojim se utvrđuju odsustvo, odnosno prisu- 
stvo, količina i rasprostranjenost dentalnog plaka i ostalih mekih naslaga na reprezentativnim stalnim zubima [6]. Za kliničku ocenu stanja gingive primenjivan je Loe-Silnessov indeks. Pomoću njega stanje gingive je ocenjivano sa vestibularne, oralne, mezijalne i distalne strane svakog prisutnog zuba [7].

Za procenu stanja parodoncijuma korišćen je CPI indeks (Community Periodontal Index) [8] po preporukama Britanske asocijacije za parodontologiju i Britanske asocijacije za dečju stomatologiju (Guidelines for Periodontal Screening and Management of Children and Adolescents Under 18 years of Age) [9]. Pri određivanju ovog indeksa korišćena je posebna parodontalna sonda specijalno graduisana na 1,2, 3, 5, 7, 9 i $10 \mathrm{~mm}$, koja na vrhu ima kuglicu prečnika $0,5 \mathrm{~mm}$. Zahvaljujući ovoj kuglici sprečava se prodiranje vrha sonde između ćelija pripojnog epitela. Ovakva podela sonde je prilagođena preciznijem merenju nivoa pripojnog epitela odnosno parodontalnih džepova.

Prilikom pregleda sonda je uz blag pritisak unošena u prostor između zuba i gingive, pri čemu je praćena anatomska konfiguracija zuba. Pritisak pri ovom merenju je 15-20 g i mnogo je manji od pritiska koji se koristi pri uobičajenom sondiranju parodontalnih džepova [8]. Ovom prilikom pregledani su sledeći reprezentativni zubi: gornji i donji prvi stalni molari, gornji desni prvi stalni sekutić i donji levi prvi stalni inciziv. Na svakom zubu vršena su četiri sondiranja i to: meziobukalno, bukalno, distooralno i oralno. U zavisnosti od kliničkog nalaza, za svaki kvadrant je određen odgovarajući broj bodova. Bodovanje je vršeno na sledeći način:

0 bodova - zdrav parodoncijum;

1 bod - krvarenje gingive posle sondiranja;

2 boda - prisustvo čvrstih naslaga na zubima (kamenac ili subgingivalni konkrementi) ili postojanje prominentnih ivica ispuna;

3 boda - prisutni plitki parodontalni džepovi 4-5 mm;

4 boda - prisutni dublji parodontalni džepovi 6 i više $\mathrm{mm}$.

Od ova četiri, upisivan je nalaz koji označava najteže stanje parodoncijuma. Za svaki kvadrant je utvrđivana samo jedna cifra od 0 do 4 koja predstavlja najteže utvrđeno stanje u tom kvadrantu. Ukoliko je neki od reprezentativnih zuba nedostajao, taj kvadrant se nije uzimao u obzir. Tako su za svakog ispitanika utvrđene najveće individualne vrednosti ovog indeksa, na osnovu kojih je bilo moguće odrediti potrebu za lečenjem i vrstu neophodnog tretmana.

Treba naglasiti da se deci uzrasta 7-11 godina ne preporučuje merenje dubine džepova, tako da se ta preporuka ispoštovala i u ovoj studiji. Naime, kod dece ispod 12 godina starosti stanje parodoncijuma se određivalo na osnovu kliničkog stanja gingive i eventualnog prisustva čvrstih naslaga [9].

U ovoj studiji nivo pripojnog epitela nije meren deci mlađoj od 12 godina, a za merenje deci starijoj od 11 godina poslužili su isti zubi kao kod CPI indeksa [9]. Merenje je vršeno graduisanom stomatološkom sondom sa milimetarskom podelom, sa kuglicom na vrhu, na sredini vestibularne površine zuba i na spoju mezijalne i vestibularne površine. Sonda je postavljana u sulkus paralelno sa uzdužnom osovinom zuba [9]. Rezultati merenja su unošeni za svaki reprezentativni zub.

Za opis parametara od značaja i u zavisnosti od njihove prirode, korišćene su mere deskriptivne statistike: srednja vrednost, standardna devijacija (SD) i procenti. Za testiranje statističke značajnosti u prosečnim vrednostima između dva nezavisna uzorka korišćen je Studentov t-test i Man-Vitnijev test. Vred- nosti p manje od 0,05 smatrale su se statistički značajnim. Statistička obrada podataka urađena je u programu SPSS v.11.5 for Windows.

\section{REZULTATI}

U istraživanju je učestvovalo ukupno 177 dece uzrasta 10-15 godina. Prosečna starost dece obolele od šećerne bolesti iznosila je $12,7 \pm 1,6$, dok je prosečna starost mališana iz kontrolne grupe bila $12,8 \pm 1,6$.

U uzorku dece koja boluju od dijabetesa prosečna vrednost PI iznosila je 1,31 $\pm 0,55$, dok je prosečna vrednost ovog indikatora u kontrolnoj grupi dece iznosila $1,03 \pm 0,51$. Deca obolela od šećerne bolesti imala su znatno više prosečne vrednosti plak indeksa u odnosu na zdravu decu (Tabela 1).

Od ukupnog broja pregledane dece iz grupe $\mathrm{D}$, zdravu gingivu ima 6,8\%, blagu inflamaciju gingive ima $17,2 \%$, umerenu inflamaciju 58,6\%, a tešku inflamaciju 17,2\%. U grupi K zdravu gingivu ima $26,7 \%$ dece, blagu inflamaciju $43,3 \%$, umerenu inflamaciju $22,2 \%$, a tešku $7,8 \%$. Ispitanici iz grupe dijabetičara imaju najviše procentualno zastupljenu umerenu i tešku inflamaciju gingive, dok ispitanici iz kontrolne grupe imaju najviše zastupljenu zdravu gingivu i blagu inflamaciju (Tabela 2). Razlike u pogledu stanja zdravlja gingive su značajne $\mathrm{u}$ korist kontrolne grupe ( $\mathrm{p}<0,05$; Man-Vitnijev test).

Značajno veći procenat dece sa zdravim parodoncijumom registrovan je kod zdrave dece - 55,6\% ( $<<0,05$; Man-Vitnijev test). Nasuprot njima, kod dece obolele od dijabetesa procentualno je bilo najzastupljenije krvarenje nakon sondiranja 36,7\%, što je bilo statistički značajno ( $\mathrm{p}<0,05$; Man-Vitnijev test). Zdrav parodoncijum u grupi D registrovan je kod $24,1 \%$ populacije, dok je prisustvo čvrstih naslaga registrovano kod $17,2 \%$, a prisustvo parodontalnih džepova od 4-5 mm kod 21,8\% populacije. Ispitanici iz kontrolne grupe imali su prisutno krvarenje nakon sondiranja kod $31,1 \%$, prisustvo čvrstih naslaga kod 7,8\% i džepove dubine 4-5 mm kod 5,6\% populacije (Tabela 3). Deca sa $\mathrm{DM}$ u odnosu na decu iz kontrolne grupe imala su značajno lošije stanje parodoncijuma ( $\mathrm{p}<0,05$; Man-Vitnijev test).

Vrednost 4 CPI indeksa nije registrovana u obe grupe.

Prosečna vrednost indeksa CPI u oboleloj grupi iznosila je $1,36 \pm 1,12$ i bila je znatno viša $(t=5,58 ; p=0,000)$ u odnosu na pripadnike zdrave grupe $(0,59 \pm 0,84)$. Ovo se jasno može videti u Tabeli 1.

Prosečna vrednost nivoa pripojnog epitela za decu obolelu od dijabetesa iznosila je $1,33 \pm 0,60$. Izmerena prosečna vrednost nivoa pripojnog epitela kod zdrave dece iznosila je 0,66 $\pm 0,53$ (Tabela 1). Zdrava deca imala su znatno niže vrednosti nivoa pripojnog epitela od obolele dece $(t=5,58 ; \mathrm{p}=0,000)$.

\section{DISKUSIJA}

Rezultati ovih istraživanja ukazuju na to da deca obolela od DMT1 imaju lošiju oralnu higijenu, veću učestalost i težinu gingivita u odnosu na zdravu decu. Isto tako, utvrdili smo da među zdravom decom ima značajno više ispitanika sa zdravim parodoncijumom. Krvarenje gingive nakon sondiranja bilo je procentualno najzastupljenije kod obolele populacije, dok je zdrav parodoncijum procentualno prednjačio kod kontrolne 
grupe. Većina studija zaključila je da je incidencija hroničnog gingivita kod pacijenata sa DMT1 značajno veća u odnosu na zdravu populaciju i povećava se sa godinama [10]. U svojim istraživanjima Daković je utvrdila da su deca sa DMT1 u Srbiji imala više dentalnog plaka, gingivita i parodontalne destrukcije, što je u saglasnosti sa rezultatima ove studije [11]. U velikoj brazilskoj studiji ustanovljeno je da deca obolela od DM imaju procentualno više gingivita i parodontitisa u odnosu na zdravu decu [12]. Deca sa DMT1 u Litvaniji i Turskoj imaju više dentalnog plaka i lošije stanje gingive u odnosu na decu iz kontrolne grupe, što je u korelaciji sa rezultatima ove studije $[13,14]$. Naime, povećan nivo glukoze u gingivalnoj tečnosti i krvi i smanjeno lučenje pljuvačke kod pacijenata sa DM menja sredinu mikroflore uzrokujući kvalitativne promene kod bakterija koje su odgovorne za nastanak parodontoloških problema $[13,15]$. Karjalainen i saradnici su primetili da je neuravnotežen metabolizam glukoze kod dijabetičara u direktnoj korelaciji sa stepenom inflamacije gingive [16]. Izrazito krvarenje gingive usled hiperglikemije može se objasniti imunološkim promenama koje se javljaju kod domaćina zbog smanjene otpornosti prema organskim naslagama dentalnog plaka.

Oboljenja parodoncijuma se navode kao česta komplikacija djabetesa melitusa [4], a prevalencija, težina i napredovanje oboljenja potpornog aparata zuba veći su kod ovih bolesnika. Rezultati brojnih studija, kao i ovog istraživanja, ukazuju da deca obolela od dijabetesa imaju procentualno više promena na parodoncijumu u odnosu na zdravu decu [10, 17-21]. Slične rezultate dobili su Daković i sar. za decu sa DMT1 u Srbiji [11]. U svojim istraživanjima Lalla i sar. zaključuju da je stepen destrukcije parodoncijuma kod dece sa DMT1 značajno viši u odnosu na zdravu decu [17]. Pa ipak, rezultati određenih istraživanja ne nalaze značajnu razliku u oboljenjima parodoncijuma između dece sa dobro kontrolisanim dijabetesom i zdrave dece $[19,22]$. Naime, oralno-higijenske navike imaju značajnu ulogu u očuvanju i održavanju potpornog aparata zuba, a pre- valencija ove bolesti varira u zavisnosti od zdravstvenih navika svake osobe.

Parodontalna oboljenja počinju veoma rano kod ove dece, sa tendencijom pogoršanja u adolescenciji. Adolescenti sa DMT1 razvijaju raniju i veću zapaljensku reakciju gingive na sličan bakterijski izazov nego pripadnici zdrave kontrolne grupe. U skladu sa ovom činjenicom, proširene studije su pokazale da se ozbiljnija oštećenja parodoncijuma češće javljaju kod onih pacijenata sa DM koji su loše metabolički regulisani [10, 11, 17, $18,19]$. Zato programe za promovisanje prevencije oboljenja parodoncijuma i lečenje treba obezbediti što ranije ovoj populacionoj grupi $[10,11,23]$.

Dijabetes je hronična metabolička bolest koja utiče na ceo organizam, naročito remeteći oralno zdravlje. Zdravstvene navike su veoma značajne u prevenciji oralnih oboljenja. Zadatak svakog stomatologa trebalo bi da bude usmeren ka negovanju dobrih zdravstveno-oralnih navika, obavljanju periodičnih stomatoloških pregleda i obezbeđivanju dobre oralne higijene kod ove populacione grupe. Ovi uslovi znatno utiču na oralno zdravlje dijabetičara. Stomatolozi moraju da svedu na minimum faktore rizika za nastanak oboljenja parodoncijuma, karijesa i mekih oralnih tkiva, kao i da sprovode kontinuiran zdravstveno-vaspitni rad i motivaciju ovih pacijenata u vezi sa oralnom higijenom [13].

\section{ZAKLJUČAK}

Rezultati ovih istraživanja ukazuju da deca obolela od dijabetesa melitusa tipa 1 u Crnoj Gori imaju više dentalnog plaka, više gingivitisa i oboljenja parodoncijuma u odnosu na decu iz kontrolne grupe. Neophodno je predložiti plan preventivnih aktivnosti usmerenih na edukaciju i primenu profilaktičkih mera, koje se odnose na smanjenje akumulacije dentalnog plaka i zubnog kamenca, individualno u stomatološkim ordinacijama. 